\title{
EVALUATING THE PHYLOGENETIC POSITION OF THE MONOTYPIC family Halophytaceae (Portulacinae, Caryophyllales) BASED ON PLASTID AND NUCLEAR MOLECULAR DATA SETS
}

\author{
Ana M. Anton ${ }^{1}$, Tania Hernández-Hernándezz ${ }^{2}$ J. Arturo De-Nova and Victoria Sosa ${ }^{2,4}$ \\ 'Instituto Multidisciplinario de Biología Vegetal, CONICET-Universidad Nacional de Córdoba, Córdoba, Argentina \\ ${ }^{2}$ Biología Evolutiva, Instituto de Ecología A.C., Xalapa, Veracruz, Mexico \\ ${ }^{3}$ Instituto de Investigación de Zonas Desérticas y Facultad de Agronomía, \\ Universidad Autónoma de San Luis Potosí, San Luis Potosí, Mexico \\ ${ }^{4}$ Author for correspondence: victoria.sosa@inecol.mx
}

\begin{abstract}
In spite of numerous phylogenetic studies to determine relationships in Order Caryophyllales and particularly in the suborder Portulacinae, the position of Halophytaceae remains controversial. Halophytum ameghinoi belongs to this monotypic succulent herbaceous family, which is endemic to the Argentine Monte eco-region, in arid and semi-arid scrubland. Some have suggested a relationship with Chenopodiaceae and others a close relationship with Basellaceae and/or Portulacaceae. We performed detailed phylogenetic analyses using the nuclear (18S, ITS, and 26S) and plastid regions (atpB, trnK/matK, ndhF, rbcL, and $r p l 16$ ) of previous and newly obtained DNA sequences in the suborder Portulacinae to clarify Halophytum's relationships and to identify the DNA markers with the strongest phylogenetic signal. Phylogenetic analyses performed with the total evidence data matrix confirmed a close relationship between Halophytum and Basellaceae and a close relationship of both with Didiereaceae. The DNA marker with the most parsimony informative sites was the plastid $\operatorname{trnK} / \mathrm{mat} K$, followed by $n d h F$. When the proportion of variable to informative sites is considered, the nuclear ITS region retrieved the most informative sites. However, phylogenetic trees retrieved by total evidence analyses improve branch support if this nuclear region is not used.
\end{abstract}

Keywords: Anredera, Basellaceae, Halophytum, ITS, ndhF, trnK/matK.

Resumen: A pesar de numerosos estudios filogenéticos para determinar las relaciones de las familias del orden Caryophyllales y particularmente del suborden Portulacinae, no se ha establecido aún la posición de Halophytaceae. Halophytum ameghinoi es el único representante de esta familia de hierbas suculentas, endémico de la ecoregión Monte Argentino, creciendo en vegetación arbustiva árida o semi-árida. Algunos autores han sugerido una relación con Chenopodiaceae y otros con Basellaceae y/o Portulacaceae y Montiaceae. Para determinar la posición de Halophytum en el suborden Portulacinae se llevaron a cabo análisis filogenéticos utilizando regiones nucleares (18S, ITS, 26S) y regiones de cloroplasto (atpB, trnK/matK, ndhF, rbcL y rpll6), de secuencias de ADN previas y secuenciadas en este proyecto. El análisis filogenético basado en la matriz de evidencia total confirmó una cercana relación entre Halophytum y Basellaceae. Estos dos grupos resultaron cercanamente emparentados con Didiereaceae. La región de ADN con mayor número de sitios variables fue la región de cloroplasto $t r n k / m a t K$ seguida por $n d h F$, aunque la región nuclear de ITS resultó con más sitios variables si se toma en cuenta el porcentaje de sitios variables/sitios informativos. Sin embargo, si esta región nuclear es eliminada, los árboles filogenéticos muestran valores de soporte de ramas más altos.

Palabras clave: Anredera, Basellaceae, Halophytum, ITS, $n d h F, \operatorname{trnK} / m a t K$.

$\boldsymbol{H}_{\mathrm{o}}$ alophytum ameghinoi (Speg.) Speg., the sole species of family Halophythaceae, is a remarkable taxon belonging to Order Caryophyllales. Halophytum is a monoecious, annual herb with decumbent, glabrous branches, small flowers in racemose inflorescences, and alternate succulent leaves (Bittrich, 1993a). Other morphological characters are rayless wood (Gibson, 1978), four petal-like elements, stamens alternate with perianth members, anthers that dehisce by pores, and cuboid, hexaporate pollen (Bittrich, 1993a). The carpellate inflorescence is fasciculate and the fruit is a nutlet, embedded in the hard inflorescence axis (Hunziker et al., 1974; Pozner and Cocucci, 2006). Halo- 
phytum is endemic to the arid and semi-arid lands of the Argentine Monte eco-region, where it is found in open scrubland and very often growing on bare soil from La Rioja in the north to Santa Cruz in the south, at elevations from sea level (the Valdés Peninsula) to 2,200 $\mathrm{m}$ (Caligasta) in areas that receive little rainfall (80-250 mm; Zuloaga and Morrone, 1999).

Halophytum ameghinoi was initially described as a member of the genus Tetragonia, in the Aizoaceae (Spegazzini, 1899). However, differences in ovary, pollen, and fruit morphology showed that this relationship is unlikely (Bittrich, 1993b); moreover, the species lacks several apomorphies of Aizoaceae (Bittrich, 1993b). Later, H. ameghinoi was classified in its own family, Halophytaceae, by Soriano (1946) who pointed out that it should be considered an independent family with uncertain, inconclusive systematic relationships with families included in Centrospermae. Pozner and Cocucci (2006) summarized the several relationships that have been proposed for Halophytaceae. A close relationship with Chenopodiaceae was proposed based on vegetative and floral characters (Hutchinson, 1959; Takhtajan, 1959; Cronquist, 1981), and because the exine structure of its pollen grains is similar to that of some Chenopodiaceae members (Skvarla and Nowicke, 1976). Other authors related Halophytum to Basellaceae or Basellaceae-Phytolaccaceae based on pollen morphology (Erdtman, 1972; Bittrich, 1993a) and the possession of P-type sieve-tube plastids (Hunziker et al., 1974), while other hypothesis suggested a close relationship with Basellaceae and/or Portulacaceae, based on stomata (Di Fulvio, 1975), floral morphology (Takhtajan, 1969, 1997), and chromosome number (Hunziker et al., 2000).

Although molecular data helped clarify the relationships among the families of Order Caryophyllales, the evolutionary relationships of Halophytum with other groups have remained elusive. Manhart and Retting (1994) suggested that this genus is related to Cactaceae, Basellaceae, Didiereaceae, and Portulacaceae in the "succulent" clade or the suborder Portulacinae (Cronquist and Thorne, 1994), which in traditional classifications includes the families Basellaceae, Cactaceae, Didiereaceae, Halophytaceae, Hectorellaceae, and Portulacaceae (Nyffeler and Eggli, 2010). Savolainen et al. (2000) performed parsimony analyses based on a plastid $r b c L$ dataset for eudicots and included a sample of Halophytum. Their results suggested a sister group relationship between this taxon and Basellaceae; however, this relationship did not receive strong support and was not retrieved with support by later studies. Cuénoud et al. (2002) published the first molecular phylogeny of Caryophyllales based on plastid $r b c L$ and matK DNA sequences with an extensive taxonomic sampling, and confirmed the inclusion of Halophytum within the suborder Portulacinae, including Montiaceae. However, they were not able to resolve relationships among families within this suborder (Figure 1A). The close relationship among families Basellaceae, Didiereaceae, Cactaceae, Portulacaceae, Halophytaceae, and Montiaceae was later confirmed by phylogenetic studies by Nyffeler and Eggli (2010) that focused on the clade and based on a plastid matK and $n d h F$ matrix, and by Ocampo and Columbus (2010) with a matrix of six concatenated plastid regions; both using Bayesian inference. The recent efforts of Nyffeler and Eggli (2010) to elucidate phylogenetic relationships within the suborder based on molecular data led them to propose a revised familial classification of Portulacineae, in which they recognized eight monophyletic families: Basellaceae, Cactaceae, and Halophytaceae, which correspond to traditionally circumscribed families; and members of traditional Portulacaceae as part of Anacampserotaceae (Anacampseros, Grahamia, Talinopsis), Didiereaceae (incl. Calyptrotheca, Ceraria, Portulacaria), Montiaceae (incl. Hectorellaceae, Calandrinia, Cistanthe, Claytonia, Lewisia, Montia, Phemeranthus), Talinaceae (Amphipetalum, Talinella, Talinum), and Portulacaceae with only one genus, Portulaca. Nevertheless, neither Nyffeler and Eggli (2010) nor Ocampo and Columbus (2010) were able to retrieve well supported topologies to determine the phylogenetic affinities between Halophytum and the other lineages. Moreover, Ocampo and Columbus (2010) ran the phylogenetic Shimodaira-Hasegawa test for alternative topologies regarding the placement of members of this clade, but none of the hypotheses for the position of Halophytum received significant support over the others, revealing the need for further analysis with additional data.

Schäferhoff et al. (2009) also attempted to improve the

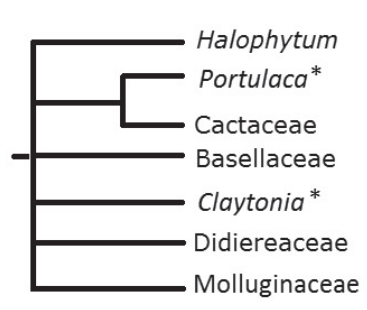

(A)

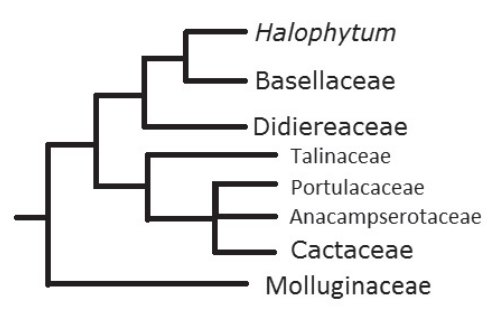

(B)

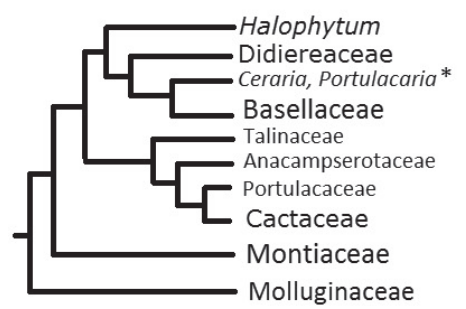

(C)

Figure 1. Schematic representation of the different hypotheses proposed for the placement of Halophytum, in relation to related families within the succulent clade using molecular data. (A) see Cuénoud et al. (2002); (B) see Schäferhoff et al. (2009); (C) see Arakaki et al. (2011). * indicates genera formerly classified in Portulacaceae. 
hypotheses of phylogenetic relationships among members of Order Caryophyllales using DNA data. They increased taxonomic sampling and used plastid petD and mat $K$ sequences, performing parsimony and Bayesian inference analyses. Their results with a combined pet $D+\operatorname{mat} K$ dataset using parsimony methods and with a $m a t K$ dataset using Bayesian methods showed a sister relationship between Halophytum and Basellaceae members, although the support values were low $(51 \%$ parsimony bootstrap and 0.8 posterior probability values). Their analyses using a petD dataset did however, suggest that Halophytum is more closely related to a clade made up of members of Basellaceae and Didiereaceae (Figure 1B), but again without good support values. This last relationship was confirmed by Brockington et al. (2009), who ran parsimony and likelihood analyses on nine plastid and two nuclear regions; Halophytum's phylogenetic position however remained unresolved.

More recently, Arakaki et al. (2011) used likelihood methods based on nuclear $p h y C$ and plastid trnK/matK with an impressive sampling of 295 representative taxa in Portulacinae. Their results improved the resolution of topologies and suggested a novel hypothesis in which Halophytum is sister to a clade composed of members of Didiereaceae and Basellaceae, with Portulacaria and Ceraria (traditionally classified within Portulacaceae and currently classified in Didiereaceae) forming a clade more closely related to Basellaceae (Figure 1C). Similar relationships were retrieved with higher bootstrap likelihood support values using a trnK/matK dataset from Crawley and Hilu (2012a, b; likelihood bootstrap support values above $50 \%$ ).

Difficulties in solving the phylogenetic affinities of $\mathrm{Ha}$ lophytum with Didiereaceae, Basellaceae and Portulacaceae in the studies mentioned, support the use of novel strategies and a different taxonomic sampling to resolve its position. In this study we compiled a dataset of eight plastid and nuclear regions available for the suborder Portulacinae (Nyffeler and Eggli, 2010) to test the phylogenetic position of Halophytum in relation to Basellaceae, Didiereaceae, and its segregates. We analyzed the phylogenetic signal in each DNA marker as well as the use of nuclear, plastid, or total evidence data matrices by comparing the results with hypotheses that are already available.

\section{Materials and methods}

Taxonomic sampling. Taxa representative of the families of Order Caryophyllales and of the suborder Portulacinae belonging to the succulent clade (Basellaceae, Cactaceae, Didiereaceae, Halophytaceae, Montiaceae, and Portulacaceae) were selected. Depending on availability on the GenBank, 11 to 132 taxa were assembled in the corresponding data matrix for each molecular marker. Representative species of Beta (Amaranthaceae), Mollugo (Molluginaceae), and Stegnosperma (Stegnospermataceae) were used as outgroups
(Species and GenBank accession numbers are listed in Appendix 1).

DNA sequencing. Nuclear DNA sequences (ITS and 18S, 26S) and plastid sequences (atpB, trnK/matK, ndhF, rbcL, rpll6) were downloaded from GenBank. Additionally, we sequenced the $n d h F$ and the rpll6 regions for Halophytum ameghinoi. DNA was extracted from fresh or silica-geldried tissue with the DNeasy Plant Mini kit (Qiagen, California, USA). The $n d h F$ region was amplified using primers 32F-1101R and 1101F-2110R, and sequenced following the protocols of Terry et al. (1997); while the rpll6 region was amplified using primers rpl16F71 and rpll6R1516, and sequenced following the protocols of Shaw et al. (2005). The sequences for each region were aligned automatically using Muscle 3.8 (Edgar, 2004), followed by a manual refinement using BioEdit 5.0.6 (Hall, 1999), 5' and 3' extremes were pruned in each matrix to leave similar length sequences for every taxon. For some cases in which DNA regions were not available for the same taxon, we assembled sequences from different species of the same genus to minimize missing data, following Campbell and Lapointe (2009).

Phylogenetic analyses. Matrices were constructed for every locus, as were concatenated nuclear, concatenated plastid, and total evidence data matrices. Bayesian inference, parsimony and maximum likelihood (ML) analyses were performed. Parsimony included only potentially informative characters, which were unordered and equally weighted. Gaps were treated as missing data and the analyses were performed in NONA 2.0 (Goloboff, 1999) using the parsimony ratchet under WinClada v.1.00.08 (Nixon, 2002) as a shell program. Three searches with different starting seeds using 300 iterations (100 trees held per iteration) were carried out. We sampled $10 \%$ of the characters for reweighting during the parsimony ratchet and calculated a strict consensus from the most parsimonious trees. Bayesian inference was run in MrBayes v3.1.2 (Huelsenbeck and Ronquist, 2001). In each single locus analysis, the best fitting substitution model was identified with jModelTest 2 (Darriba et al., 2012). In the concatenated data sets, each locus was treated as a partition for which its best fitting model was specified, and unlinked parameter estimation and independent rate variation were allowed. The Metropolis-coupled Markov chain Monte Carlo (MC3) consisted of two independent runs of 10 million generations during which one was sampled every 200 trees. The outputs of MrBayes were examined with Tracer v1.4 (Rambaut and Drummond, 2007) to check for any convergence of different parameters, to determine the approximate number of generations at which log likelihood values stabilized to identify the effective sample size (ESS) for each parameter, and to estimate the magnitude of model parameters in individual and combined runs. Topological convergence in the two independent MCMC runs was checked with the 

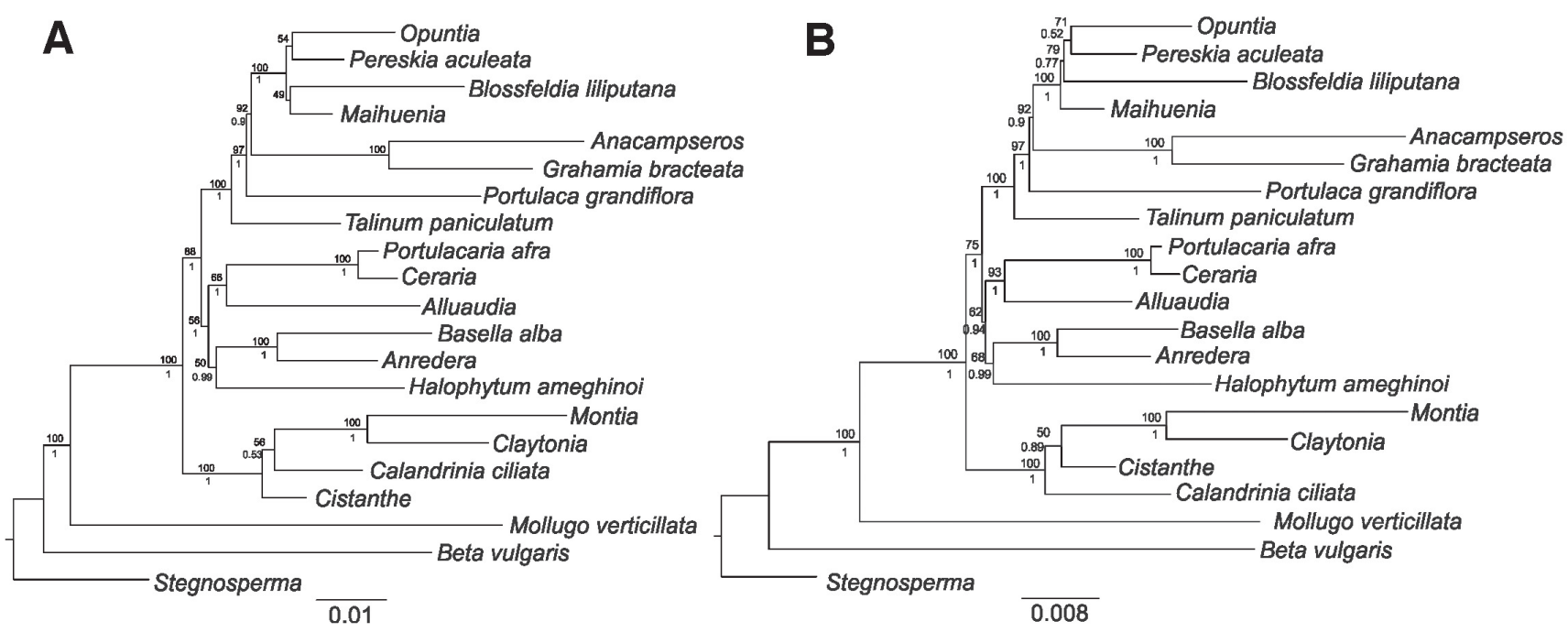

Figure 2. (A) ML topology estimated for the succulent clade using the concatenated total evidence data matrix. (B) ML topology estimated for the succulent clade using the total evidence data matrix without the nuclear ITS region. Values above and below branches correspond to ML bootstrap and posterior probability values, respectively. Genera with no species name correspond to assembled sequences from different species of the same genus to minimize missing data.

"compare" plot in AWTY (Wilgenbusch et al., 2004). The initial $10 \%$ of MCMCs was verified to include all the generations before stationarity. The posterior probabilities of clades were obtained from the $50 \%$ majority rule consensus of sampled trees after excluding the initial $10 \%$ as burn-in. Maximum likelihood analyses were performed in RAxML v.7.0.4 (Stamatakis, 2006). For the concatenated matrices, we implemented an independent general time reversible model (GTR) and a gamma distribution for site rates for each data partition. We set 25 rate categories for the gamma distribution for each locus in the single locus analyses and for each partition in the concatenated matrix analyses because an exploratory analysis in RAxML showed this number of categories leads to an improvement in likelihood values. We performed 500 independent searches starting from different initial MP trees. The ML tree was selected from the entire set of resulting trees on each search.

Statistical support for the position of Halophytum ob-

Table 1. Number of taxa, DNA markers, number of base pairs, and variable sites in the phylogenetic analyses performed in this study for the suborder Portulacinae.

\begin{tabular}{|c|c|c|c|c|c|c|c|}
\hline Region & Source & No. Taxa & Length (bp) & $\begin{array}{l}\text { Constant } \\
\text { sites }\end{array}$ & $\begin{array}{l}\text { Variable } \\
\text { sites }\end{array}$ & $\begin{array}{l}\text { Parsimony } \\
\text { informative } \\
\text { sites }\end{array}$ & $\begin{array}{c}\text { Proportion } \\
\text { variable } \\
\text { sites/info. sites }\end{array}$ \\
\hline ITS & nucleus & 93 & 878 & 364 & 465 & 355 & $52.96 / 40.43$ \\
\hline $\operatorname{atp} B$ & chloroplast & 21 & 2,306 & 1,225 & 269 & 104 & $11.66 / 4.50$ \\
\hline$n d h F$ & chloroplast & 49 & 2,134 & 1,380 & 733 & 475 & $34.34 / 22.25$ \\
\hline$r b c L$ & chloroplast & 58 & 1,430 & 1,116 & 283 & 155 & $19.79 / 10.83$ \\
\hline $\begin{array}{c}\text { Plastid (atpB, } \\
\text { trnK/matK, ndhF, } \\
r b c L, r p / 16)\end{array}$ & chloroplast & 25 & 9,757 & 6,374 & 2,346 & 972 & $24.04 / 9.96$ \\
\hline Total evidence & $\begin{array}{l}\text { nucleus and } \\
\text { chloroplast }\end{array}$ & 21 & 15,232 & 11,260 & 2,843 & 1,105 & $18.66 / 7.25$ \\
\hline
\end{tabular}




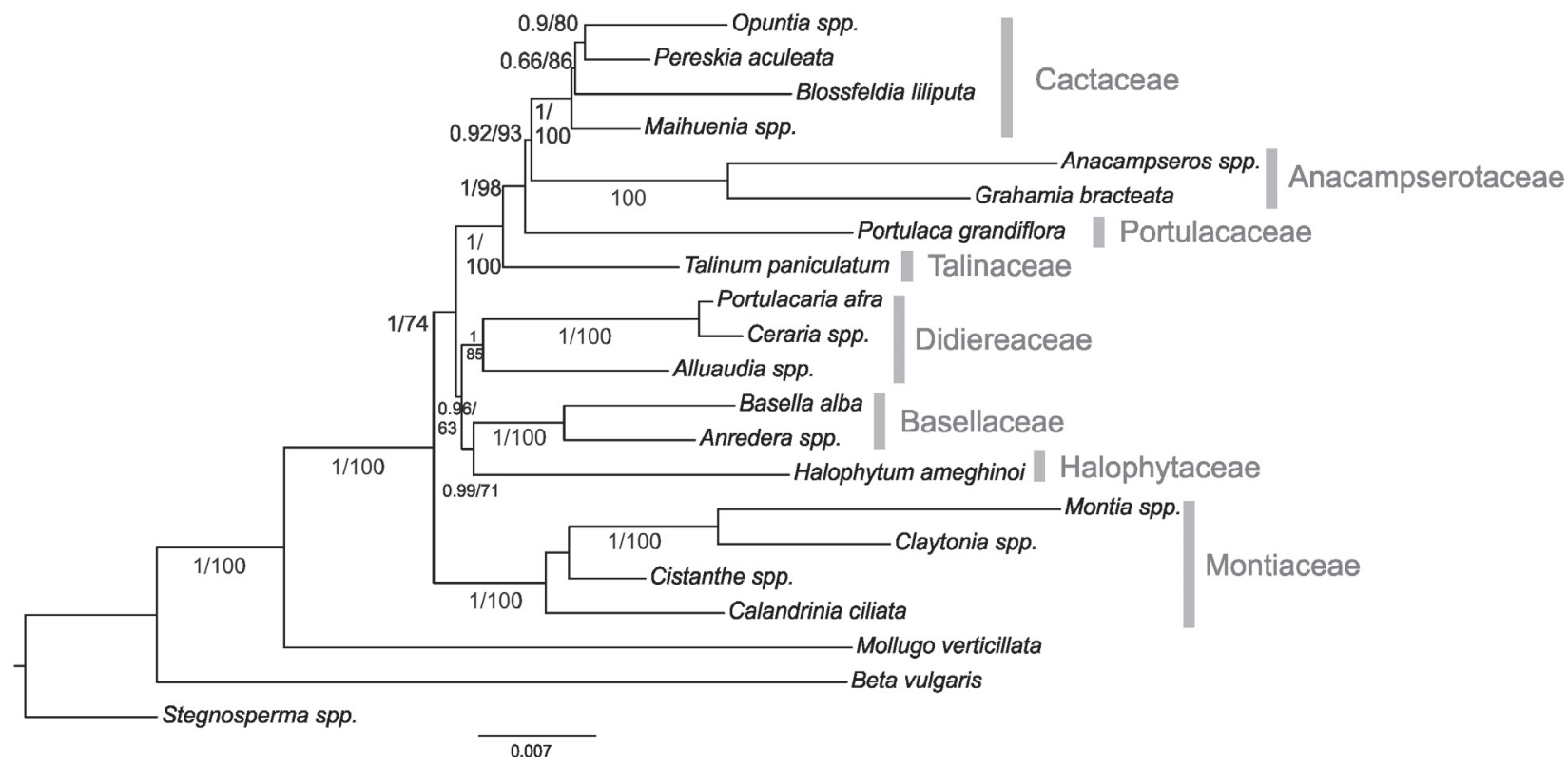

Figure 3. Best ML topology estimated for the succulent clade using a matrix with two nuclear (18S, and 26S) and four plastid regions $(a t p B, \operatorname{trnK} / m a t K, n d h F$, and $r b c L)$. Values above and below branches correspond to ML bootstrap and Bayesian posterior probability values, respectively. Genera with no species name correspond to assembled sequences from different species of the same genus to minimize missing data.

tained with each region and the concatenated matrices in the parsimony analyses were evaluated using TNT (Goloboff $e t$ al., 2008), running 1000 replicates in the "traditional search" approach with TBR set to 100 replications holding 50 trees, and saving the consensus of each resampling matrix. For the Bayesian analyses statistical support was evaluated using the posterior probability (pp) values obtained from the $\mathrm{Mr}$ Bayes analyses, and for the maximum likelihood. We performed 100 ML bootstrap (bst) replicates in RAxML.

\section{Results}

Table 1 includes information for every data matrix. In general, the plastid matrix included more information in terms of variable $(\mathrm{V})$ and parsimony informative $(\mathrm{Pi})$ sites than the nuclear matrix did, although the locus with the highest number of $\mathrm{V}$ and Pi sites was the ITS region, $\operatorname{trnK} / \mathrm{mat} K$ and $n d h F$ regions had the highest number of $\mathrm{V}$ and $\mathrm{Pi}$ sites on the plastid markers used. The $t r n K / m a t K$ data matrix had the highest taxonomic sampling including 132 taxa, followed by ITS (93 taxa) and $r b c L$ (58 taxa; Table 1). However, it is important to point out that the number of taxa sampled does not necessarily reflect the heterogeneity of lineages within Caryophyllales.

Trees resulting from parsimony, Bayesian, and maximum likelihood analyses for each separate locus can be obtained on request from the author for correspondence. Parsimony analyses did not resolve the relationship of Halophytum with the taxa included in any matrix. The hypothesis proposed by Schäferhoff et al. 2009 (Figure 1B), in which Halophytum is more closely related to Basellaceae, was supported by the ITS and $n d h F$ regions, and by the plastid and total evidence analyses, both with Bayesian inference and ML results. The hypothesis proposed by Arakaki et al. (2011; Figure 1C), in which Halophytum is the sister group to the BasellaceaeDidiereaceae clade (and Ceraria and Portulacaria, formerly placed in the paraphyletic Portulacaceae), was only supported by the $\operatorname{trnK} / \mathrm{mat} K$ region.

The total evidence matrix included five plastid and three nuclear regions, reaching a total of 15,232 bp (Table 1). The best resolved topologies are shown in figures 2 and 3. ML and Bayesian hypotheses were congruent; thus, the trees synthesize relationships, showing support values above 50\% for the ML bootstrap (bst) and above 0.5 for posterior probability values (pp) for the Bayesian inference. The ML tree in Figure 2A was retrieved from the total evidence analysis. Figure 2B was retrieved when the nuclear ITS was removed from the data matrix. Figure 3 shows the tree based on a data matrix in which the nuclear ITS and the plastid rpll6 were eliminated. This phylogenetic hypothesis had the highest support values ( $b s t=64, \mathrm{pp}=0.96$ ) for the clade formed by the three representative taxa of Didiereaceae, the two representative taxa of Basellaceae and Halophytum. Moreover, $H$. ameghinoi was the sister taxon to the Basellaceae in a well-supported clade $(\mathrm{bst}=100, \mathrm{pp}=1)$.

\section{Discussion}

Suborder Portulacinae, that includes the families Basellaceae, Cactaceae, Didiereaceae, Halophytaceae, and Por- 
tulacaceae, was originally proposed by Engler (1898) and recognized by Thorne as suborder Cactinae (Thorne, 1976; 2000). The suborder has been identified as monophyletic in a number of systematics studies (e.g. Hershkovitz and Zimmer, 1997; Applequist and Wallace, 2001; Cuénoud et al., 2002; Hilu et al., 2003; Applequist et al., 2006; Nyffeler, 2007; Schäferhoff et al., 2009; Arakaki et al., 2011). However, the majority of these did not include sequences of Halophytum to define its evolutionary relationships.

Although our parsimony analyses did not retrieve topologies with a strong resolution in terms of bootstrap support for nodes in any of the matrices analyzed, phylogenetic analyses performed using Bayesian inference and maximum likelihood approaches provided topologies with enough resolution to evaluate hypotheses pertaining to the phylogenetic placement of Halophytum. Moreover, the trees retrieved by both methods were congruent. The datasets with the most balanced representation of taxa were the nuclear ITS data matrix and the plastid trnK/matK data matrix, as well as the plastid and total evidence matrices.

From the six single locus data matrices, the nuclear 26S dataset did not provide any further information for establishing the relationships of Halophytum, thus corroborating the results of Cuénoud et al. (2002), in which this DNA marker only identified the position of Halophytum in suborder Portulacinae. Two regions supported a closer relationship of Halophytum with Basellaceae (ITS and $n d h F$ ), the latter with good support. In addition, two other regions supported a novel hypothesis, in which Halophytum would be closer to the representative taxa in Montiaceae ( $a t p B$ and $r b c L$ ), though with moderate to low support. Finally, the $\operatorname{trnK} / \mathrm{mat} K$ region alone supported the relationship of Halophytum with a clade formed by Didiereaceae and Basellaceae, the clade receiving moderate to good support and confirming the results of Arakaki et al. (2011). The analyses performed with a single locus provided low support, and the conflicting results may be due to a weak phylogenetic signal rather than incongruent topologies among the DNA markers utilized (Crawley and Hilu, 2012a). The analyses performed without ITS and in addition without rpll6 were the best supported.

Our results confirm the close affinity between Halophytum and Basellaeae, previously suggested by Bittrich (1993b) due to similarly shaped cuboid pollen grains, by Di Fulvio (1975) based on stomata, by Takhtajan $(1969,1997)$ based on floral characters, and by Hunziker et al. (2000) based on the same chromosome number. Basellaceae is native to the tropical and subtropical areas of the Americas, southeastern Africa, and Madagascar, and most of its species are succulent vines with bisexual flowers occurring in dry habitats (Eriksson, 2007). Within the family, the genera Anredera, Tournonia, and Ullucus are native to the Americas, the latter two are restricted to the Andes in South America. Most Anredera species are also Andean, except for one species that is distributed as far north as the southern United States (Eriksson, 2007) and three that grow in Argentina: A. cordifolia, A. krapovickasii and A.tucumanensis.

Our analyses identified that Basellaceae and Halophytaceae are related to Didiereaceae. This family is native to the arid southwestern part of Madagascar (Erbar and Leins, 2006). Several lines of evidence suggest that Basellaceae, Cactaceae and Didiereaceae (and possibly Halophytum) originated in the paraphyletic Portulacaceae (see references in Eriksson, 2007).

The use of multiple genomic regions with variable tempos and modes of evolution, regardless of the incomplete taxonomic representation of some of them, improved the phylogenetic signal in the Caryophyllales (Crawley and Hilu, 2012a). Our results confirmed that using all plastid and nuclear regions (with exception of the nuclear ITS and the plastid rpllo) phylogenetic signal improved and the relationships of $\mathrm{Ha}$ lophytum were clarified. However, as Crawley and Hilu (2012a, b) indicated, the rapid diversification of members of the succulent clade produced incongruent topologies and insufficient support in the phylogenetic analyses. The most problematic DNA marker for aligning was rpll6, thus removing this region improved branch support. Reports of ITS region (ITS 1, 5.8S and ITS 2) in flowering plants suggested that polymorphic individuals often contain non-functional nrDNA (pseudogenes; Bailey et al., 2003). Moreover, a molecular study of the cactus Mammillaria found that most of ITS copies are non-functional and suggested a non-concerted evolution of ITS 1 and ITS 2 (Harpke and Peterson, 2006). We suggest this is the reason that the resolution of the resulting topologies in our study improved when ITS is removed from the total evidence analyses.

\section{Conclusions}

Halophytum was retrieved as the sister taxon to the representative species of Basellaceae, and both groups were sister to the Didiereaceae. The plastid marker $\operatorname{trnK}$-matK was the region with the most polymorphisms from the nuclear and plastid sequences utilized in this study. The DNA marker with the most parsimony informative sites was the plastid $\operatorname{trnK} / \mathrm{mat} K$, followed by $n d h F$; however, if the proportion of variable to informative sites is considered, the nuclear ITS region retrieved the most informative sites. A concatenated data matrix with two nuclear (18S and 26S), and four plastid regions ( $a t p B, t r n K / m a t K, n d h F$, and $r b c L)$ retrieved the best supported topologies in both the maximum likelihood and Bayesian inference analyses. Removing the nuclear ITS and the plastid rpll6 improved branch support in the topologies retrieved by Bayesian inference and ML analyses. Three species of Anredera in Basellaceae are distributed in Argentina and share pollen, floral, and vegetative characters with Halophytum. 


\section{Acknowledgments}

We are grateful to two anonymous reviewers for their valuable comments. To Alejandra Romanutti for assistance in the field. We also thank Arith Pérez and Cristina Bárcenas for their help in the lab. Lab and fieldwork was partially supported by a grant from the "México-Argentina CONACyTMYNCYT" program (B000.74/12) to AA and VS.

\section{Literature cited}

Arakaki M., Christin P.A., Nyffeler R., Lendel A., Eggli U., Ogburn R.M., Spriggs E., Moore M.J. and Edwards E.J. 2011. Contemporaneous and recent radiations of the world's major succulent plant lineages. Proceedings of the National Academy of Sciences of the United States of America 108:8379-8374.

Applequist W.L. and Wallace R.S. 2001. Phylogeny of the portulacaceous cohort based on $n d h F$ sequence data. Systematic Botany 26:406-419.

Applequist W.L, Wagner W.L., Zimmer E.A. and Nepokroeff M. 2006. Molecular evidence resolving the systematic position of Hectorella (Portulacaceae). Systematic Botany 31:310-319.

Bailey C.D., Carr T.G., Harris S.A. and Hughes C.E. 2003. Characterization of angiosperm nrDNA polymorphism, paralogy, and pseudogenes. Molecular Phylogenetics and Evolution 29:435-455.

Bittrich V. 1993a. Halophytaceae. In: Kubitzki K., Rohwer J.G. and Bittrich V. Eds. The Families and Genera of Vascular Plants, Vol II, pp. 320-321, Springer, Berlin.

Bittrich V. 1993b. Introduction to Centrospermae. In: Kubitzki K., Rohwer J.G. and Bittrich V. Eds. The Families and Genera of Vascular Plants, Vol II, pp. 13-19, Springer, Berlin.

Brockington S.F., Alexandre R., Ramdial J., Moore M.J., Crawley S., Dhingra A., Hilu K., Soltis D.E. and Soltis P.S. 2009. Phylogeny of the Caryophyllales sensu lato: revisiting hypotheses on pollination biology and perianth differentiation in the core Caryophyllales. International Journal of Plant Sciences 170:627-643.

Campbell V. and Lapointe F.J. 2009. The use and validity of composite taxa in phylogenetic analysis. Systematic Biology 58:560-572.

Crawley S.S. and Hilu K.W. 2012a. Impact of missing data, gene choice, and taxon sampling on phylogenetic reconstruction: the Caryophyllales (angiosperms). Plant Systematics and Evolution 298:297-312.

Crawley S.S. and Hilu K.W. 2012b. Caryophyllales: evaluating phylogenetic signal in trnK intron versus matK. Journal of Systematics and Evolution 50:387-410.

Cronquist A. 1981. An Integrated System of Classification of Flowering Plants. Columbia University Press, New York.

Cronquist A. and Thorne R.F. 1994. Nomenclatural and taxonomic history. In: Behnke H.D. and Mabry T.J. Eds. Caryophyllales: Evolution and Systematics, pp. 87-121, Springer-Verlag, Berlin.

Cuénoud P., Savolainen V., Chatrou L.W., Powell M., Grayer R.J. and Chase M.W. 2002. Molecular phylogenetics of Caryophyllales based on nuclear $18 \mathrm{~S}$ rDNA and plastid $r b c L, a t p B$, and $m a t K$ DNA sequences. American Journal of Botany 89:132-144.

Darriba D., Taboada G.L., Doallo R. and Posada D. 2012. jMo-
delTest 2: more models, new heuristics and parallel computing. Nature Methods 9:772.

Di Fulvio T.E. 1975. Estomatogénesis en Halophytum ameghinoi (Halophytaceae). Kurtziana 8:17-29.

Edgar R.C. 2004. MUSCLE: Multiple sequence alignment with high accuracy and high throughput. Nucleic Acids Research 32:1792-1797.

Engler A. 1898. Syllabus der Pflanzenfamilien: Eine Übersicht über das gesamte Pflanzensystem mit Berücksichtigung der Medicinal und Nutzpflanzen, zum Gebrauch bei Vorlesungen und Studien über spezielle und medicinisch-pharmaceutische Botanik. $2^{\text {nd }}$ ed. Gebrüder Borntraeger, Berlin.

Erbar C. and Leins P. 2006. Floral ontogeny and systematic position of the Didiereaceae. Plant Systematics and Evolution 261:165-185.

Erdtman G. 1972. Pollen Morphology and Plant Taxonomy: Angiosperms. Hafner Publishing Company, New York.

Eriksson R. 2007. A synopsis of Basellaceae. Kew Bulletin 62:297320 .

Gibson A.C. 1978. Rayless secondary xylem of Halophytum. Bulletin of the Torrey Botanical Club 105:39-44.

Goloboff P.A. 1999. NONA (NO NAME) ver. 2. Published by the author, Tucuman.

Goloboff P.A., Farris J.S. and Nixon K.C. 2008. TNT, a free program for phylogenetic analysis. Cladistics 24:774-786.

Hall T.A. 1999. BioEdit: a user-friendly biological sequence alignment editor and analysis program for Windows 95/98/NT. Nucleic Acids Symposium Series 41:95-98.

Harpke D. and Peterson A. 2006. Non-concerted ITS evolution in Mammillaria (Cactaceae). Molecular Phylogenetics and Evolution 41:579-593.

Hershkovitz M.A. and Zimmer E.A. 1997. On the evolutionary origins of the cacti. Taxon 46: 217-242.

Hilu K.W., Borsch T., Müller K., Soltis D.E., Soltis P.S., Savolainen V., Chase M.W., Powell M.P., Alice L.A., Evans R., Sauquet H., Neinhuis C., Slotta T.A.B., Rohwer J.G., Campbell C.S. and Chatrou L.W. 2003. Angiosperm phylogeny based on $m a t K$ sequence information. American Journal of Botany 90:1758-1776.

Huelsenbeck J.P. and Ronquist F. 2001. MRBAYES: Bayesian inference of phylogenetic trees. Bioinformatics 17:754-755.

Hunziker J.H., Behnke H.D., Eifert I.J. and Mabry T.J. 1974. Halophytum ameghinoi: a betalain-containing and P-type sieve-tube plastid species. Taxon 23:537-539.

Hunziker J.H., Pozner R. and Escobar A. 2000. Chromosome number in Halophytum ameghinoi (Halophytaceae). Plant Systematics and Evolution 221:125-127.

Hutchinson J. 1959. The Families of Flowering Plants. Vol. 1. Macmillan and Company, London.

Manhart J.R. and Rettig J.H. 1994. Gene sequence data. In: Behnke H.D. and Mabry T.J. Eds. Caryophyllales: Evolution and Systematics, pp. 235-246, Springer-Verlag, Berlin.

Nixon K.C. 2002. WinClada, Version 1.00.08. Published by the author, Ithaca.

Nyffeler R. 2007. The closest relatives of cacti: insights from phylogenetic analyses of chloroplast and mitochondrial sequences with special emphasis on relationships in the tribe Anacampseroteae. American Journal of Botany 94:89-101.

Nyffeler R. and Eggli U. 2010. Disintegrating Portulacaceae: A new familial classification of the suborder Portulacinae (Caryo- 
phyllales) based on molecular and morphological data. Taxon 59:227-240.

Ocampo G. and Columbus J.T. 2010. Molecular phylogenetics of suborder Cactineae (Caryophyllales), including insights into photosynthetic diversification and historical biogeography. American Journal of Botany 97:1827-1847.

Pozner R. and Cocucci A. 2006. Floral structure, anther development, and pollen dispersal of Halophytum ameghinoi (Halophytaceae). International Journal of Plant Sciences. 167:1091-1098.

Rambaut A. and Drummond A.J. 2007. Tracer v1.4. <http://beast. bio.ed.ac.uk/Tracer> (accessed March 1, 2013).

Savolainen V., Fay M.F., Albach D.C., Backlund A., van der Bank M., Cameron K.M., Johnson S.A., Lledó M.D., Pintaud J.C., Powell M., Sheahan M.C., Soltis D.E., Soltis P.S., Weston P., Whitten W.M., Wurdack K.J. and Chase M.W. 2000. Phylogeny of the Eudicots: A nearly complete familial analysis based on rbcL gene sequences. Kew Bulletin 55:257-309.

Schäferhoff B., Müller K.F. and Borsch T. 2009. Caryophyllales phylogenetics: disentangling Phytolaccaceae and Molluginaceae and description of Microteaceae as a new isolated family. Willdenowia 39:209-228.

Shaw J., Lickey E.B., Beck J.T., Farmer S.B., Liu W., Miller J., Siripun K.C., Winder C.T., Schilling E.E. and Small R.L. 2005. The tortoise and the hare II: relative utility of 21 noncoding chloroplast DNA sequences for phylogenetic analysis. American Journal of Botany 92:142-166.

Skvarla J.J. and Nowicke J.W. 1976. Ultrastructure of pollen exine in Centrospermous families. Plant Systematics and Evolution 126:55-78.

Soriano A. 1946. Halophytaceae. Nueva familia del orden Cen- trospermae. Notas Museo La Plata 11 Botánica 52:161-175.

Spegazzini C. 1899. Nova addenda ad floram patagonicam. Pars I. Anales de la Sociedad Científica Argentina 48:52.

Stamatakis A. 2006. RAxML-VI-HPC: Maximum likelihood-based phylogenetic analyses with thousands of taxa and mixed models. Bioinformatics 22:2688-2690.

Takhtajan A. 1959. Die Evolution der Angiospermen. Gustav Fischer, Jena.

Takhtajan A. 1969. Flowering Plants, Origin and Dispersal. Oliver \& Boyd, Edinburgh.

Takhtajan A. 1997. Diversity and Classification of Flowering Plants. Columbia University Press, New York.

Terry R.G., Brown G.K. and Olmstead R.G. 1997. Examination of subfamilial phylogeny in Bromeliaceae using comparative sequencing of plastid locus ndhF. American Journal of Botany 84:664-670.

Thorne R.F. 1976. A phylogenetic classification of the Angiospermae. Evolutionary Biology 9:35-106.

Thorne R.F. 2000. The classification and geography of the flowering plants: Dicotyledons of the class Angiospermae (subclasses Magnoliidae, Ranunculidae, Caryophyllidae, Dilleniidae, Rosidae, Asteridae, and Lamiidae). Botanical Review 66:441-647.

Wilgenbusch J.C., Warren D.L. and Swofford D.L. 2004. AWTY: A system for graphical exploration of MCMC convergence in $B a-$ yesian phylogenetic inference. <http://ceb.csit.fsu.edu/awty> (accessed March 1, 2013).

Zuloaga F.O. and Morrone O. 1999. Catálogo de las Plantas Vasculares de la República Argentina II. Missouri Botanical Garden, St. Louis.

Received: April 29th, 2013

Accepted: September 16th, 2013 
Phylogenetic Relationships of Halophytaceae

Appendix 1. Taxa and GenBank accession numbers for sequences used in this study. A dash indicates the sequence is not available for the species. Accession numbers are given in the following order: 26S, 18S, ITS, atpB, trnK/matK, ndhF, rbcL, and $r p / 16$.

OUTGROUPS: Stegnosperma cubense A. Rich.: -; -; EF079500; -; JQ588611; -; JQ593146; EF079596. Stegnosperma halimifolium Benth.: HQ843465; -; -; -; -; HQ843287; -; -. Beta vulgaris L.: -; FJ669720; AY858597, DQ223064, DQ223071; DQ067451; AY514832; HM630042; DQ067450; -. MOLLUGINACEAE: Mollugo verticillata L.: AF479088, HQ843455; HQ843431, U42828; EU410353, EU434728, EU434729, L78093; HQ620745; FN825743; AF194827; HQ621337; -. MONTIACEAE: Calyptridium monandrum Nutt.: -; -; DQ090372, CFJ614018, FJ614019, FJ614020; -; HQ620859; AF194840; -; -. Claytonia acutifolia Pall. ex Schult.: -; -; -; -; AY764097; -; -; -. Claytonia arctica Adam; -; -; -; -; AY764096; -; -; -. Claytonia arenicola Hend.: -; -; -; -; AY764088; -; -; -. Claytonia caroliniana Michx.: -; -; AY764048, AY764049; -; AY764098; -; HQ590039; -. Claytonia cordifolia S.Watson: -; -; -; -; AY764100; -; -; -. Claytonia exigua Torr. \& A.Gray: -; -; -; -; AY764089; -; -; -. Claytonia gypsophiloides Fisch. \& C.A.Mey.: -; -; -; -; AY764090; -; -; -. Claytonia joanneana Schult.: -; -; -; -; AY764101; -; -; -. Claytonia lanceolata Pursh: -; -; -; -; AY764102; -; -; -. Claytonia megarhiza (A.Gray) Parry ex S.Watson: -; -; AY764053, DQ090126, DQ498062, L78027; GQ497650; AY764103; -; -; -. Claytonia nevadensis S.Watson: -; -; -; -; AY764104; -; -; -. Claytonia ogilviensis McNeill: -; -; -; -; AY764105; -; -; -. Claytonia palustris Swanson \& Kelley: -; -; -; -; AY764106; -; -; -. Claytonia parviflora Douglas ex Hook.: -; -; -; -; AY764092, AY764093; -; -; -. Claytonia perfoliata Donn ex Willd.: -; GQ497578; -; -; AY764091; -; AF132093; -. Claytonia sarmentosa C.A.Mey.: -; -; -; -; AY764107; -; -; -. Claytonia saxosa Brandegee: -; -; -; -; AY764094; -; -; -. Claytonia scammaniana Hultén: -; -; -; -; AY764108; -; -; -. Claytonia sibirica L.: -; -; -; -; AY764109; -; -; -. Claytonia tuberosa Pall. ex Schult.: -; -; -; -; AY764110, AY764111; -; -; -. Claytonia umbellata S.Watson: -; -; -; -; AY764112; -; -; -. Claytonia virginica L.: HQ843445; HQ843427; -; HQ843256; AY764113; AF194856; -; -. Claytonia washingtoniana (Suksd.) Suksd.: -; -; -; -; AY764095; -; -; -. Hectorella caespitosa Hook.f.: -; -; -; -; EF551350; DQ093963; DQ267193; -. Lewisia columbiana (Howell ex A. Gray) B.L. Rob.: -; -; AY764085, DQ090123, DQ498101; -; AY764126; -; -; -. Lewisia longipetala (Piper) S. Clay: -; -; DQ498108; -; HQ620876; -; -; -. Lewisia pygmaea (A. Gray) B.L. Rob.: -; -; -; -; -; AF194847; -; -. Lewisia rediviva Pursh: -; -; AY764086, DQ090124, L78030; -; AY764125; -; -; -. Lyallia kerguelensis Hook.f.: -; -; -; -; EF551349; -; EF551348; -. Montia bostockii (A.E.Porsild) S.L.Welsh: -; -; -; -; AY764114; -; -; -. Montia chamissoi (Ledeb. ex Spreng.) Greene: -; -; -; -; AY764120; -; -; -. Montia dichotoma (Nutt.) Howell: -; -; -; -; AY764115; -; -; -. Montia diffusa Greene: -; -; -; -; AY764121; AF194848; -; -. Montia fontana L.: -; -; AY764072, AY764073, AY764074; -; AY764118, JN895972; -; JN891226; -. Montia howellii S. Watson: -; -; -; -; AY764117; -; -; -. Montia linearis (Douglas ex Hook.) Greene: -; -; -; -; AY764116; -; -; -. Montia parvifolia (Moc. ex DC.) Greene: -; -; -; -; AY764122; AF194851; -; -. Montia perfoliata (Donn ex Willd.) Howell: -; -; -; -; -; AF194831; -; -. Montiopsis andicola (Gillies ex Hook. \& Arn.) D.I. Ford: -; -; AF084154, AF084175, DQ090437; -; JQ780480; -; -; -. Montiopsis berteroana (Phil.) D.I.Ford: -; -; -; -; -; AF194849; -; -. Montiopsis capitata (Hook. \& Arn.) D.I. Ford: -; -; DQ090403, DQ090431, DQ090432; -; JQ780481; -; -; -. Montiopsis cumingii (Hook. \& Arn.) D.I. Ford: -; -; -; -; JQ780482; -; -; -. Montiopsis gayana (Barnéoud) D.I.Ford: -; -; -; -; -; AF194850; -; -. Montiopsis gilliesii (Hook. \& Arn.) D.I. Ford: -; -; -; -; HQ620880; -; -; -. Montiopsis ramosissima (Hook. \& Arn.) D.I. Ford: -; -; -; -; JQ780483; -; -; -. Montiopsis umbellata (Ruiz \& Pav.) D.I.Ford: -; -; -; -; -; AF194837; -; -. Phemeranthus brevifolius (Torr.) Hershkovitz: -; -; L78038; -; -; -; -; -. Phemeranthus confertiflorus (Greene) Hershkovitz: -; -; L78039; -; HQ620885; -; -; -. Phemeranthus multiflorus (Rose \& Standl.) G. Ocampo: -; -; -; -; EU834747; -; -; -. Phemeranthus spinescens (Torr.) Hershkovitz: -; -; L78040; -; -; -; -; -. Phemeranthus teretifolius (Pursh) Raf.: -; -; -; -; EU834749; -; -; -. HALOPHYTACEAE: Halophytum ameghinoi Speg.: HQ843450; HQ843429; EU410352; GQ497647; KF951094; KF951095; AJ403024; KF951097. DIDIEREACEAE: Alluaudia ascendens (Drake) Drake: HQ843440; -; -; -; AY042541; HQ843264; -; AF101128. Alluaudia comosa (Drake) Drake: -; -; -; -; HQ620838; -; -; AF101129. Alluaudia dumosa (Drake) Drake: -; -; L78011; -; HQ620839; -; -; AF101130. Alluaudia humbertii Choux: -; -; -; -; HQ620840; AF194832; -; AF101131. Alluaudia montagnacii Rauh: -; -; -; -; HQ620841; -; -; AF101132. Alluaudia procera (Drake) Drake: -; -; L78084; GQ497645; HQ620842; -; M62563; AF101133. Alluaudiopsis fiherenensis Humbert \& Choux: -; -; -; -; AY042542; -; -; AF101136. Alluaudiopsis marnieriana Rauh: -; -; -; -; HQ620843; -; -; AF101137. Decarya madagascariensis Choux: -; -; -; -; AY042574; AF194844; -; AF101138. Didierea madagascariensis Baill.: -; -; -; HQ620743; HQ620831; HQ620943; HQ621335; AF101134. Didierea trollii Capuron \& Rauh: -; -; -; -; AY042576; AF194845; -; AF101135. BASELLACEAE: Anredera baselloides (Kunth) Baill.: -; -; -; HQ620741; HQ620830; HQ620942; 
Ana M. Anton $E T$ AL.

Appendix 1. Continuation.

HQ621333; -. Anredera brachystachys (Moq.) Sperling: -; -; -; -; FN597626; -; -; -. Anredera cordifolia (Ten.) Steenis: -; -; L78086; -; AY042547; -; AY270147; -. Anredera ramosa (Moq.) Eliasson: -; -; -; -; HQ62085; -; -; -. Basella alba L.: HQ843442; GQ497567, HQ843426; L78018; GQ497643; AY042553; HQ843267; M62564; -. Basella excavata Elliot: -; -; L78019; -; -; -; -; -. Ullucus tuberosus Caldas: -; -; -; -; HQ620896; AF194865; -; -. TALINACEAE: Talinella microphylla Eggli: -; -; L78053; -; -; -; -; -. Talinella pachypoda Eggli: -; -; L78054; -; DQ855846; -; -; -. Talinella sp.: -; -; -; -; AY514859; -; -; -. Talinum caffrum (Thunb.) Eckl. \& Zeyh.: -; -; L78055; -; AY042662; AF194859; HM850388; AY851610. Talinum fruticosum Macfad.: -; -; -; -; DQ855844; DQ855865; -; -. Talinum lineare Kunth: -; -; -; -; EU834752; -; -; -. Talinum paniculatum (Jacq.) Gaertn.: HQ843466; HQ843439; EU410357, JF508608, L78094; HQ843263; AY015274; JF508755, HQ843289; -; -. Talinum paraguayense Speg.: -; -; L78056; -; -; -; -; -. Talinum polygaloides Gillies ex Arn.: -; -; -; -; DQ855845; DQ855867; -; -. Talinum portulacifolium (Forssk.) Asch. ex Schweinf.: -; -; L78057; -; DQ855847; DQ855869; -; -. Talinum spathulatum Engelm. ex A. Gray: -; -; -; -; HQ620890; -; -; -. ANACAMPSEROTACEAE: Anacampseros alta Poelln.: -; -; -; -; HQ620844, HQ620844; -; -; -. Anacampseros arachnoides (Haw.) Sims: -; -; -; -; HQ620845; -; -; -. Anacampseros australiana J.M.Black: -; -; L78013; -; -; -; -; -. Anacampseros baeseckei Dinter ex Poelln.: -; -; -; -; HQ620846; -; -; -. Anacampseros filamentosa (Haw.) Sims: -; -; -; -; HQ620847; -; -; -. Anacampseros gracilis Poelln.: -; -; -; -; HQ620848; -; -; -. Anacampseros karasmontana Dinter: -; -; -; -; DQ855859; DQ855872; -; -. Anacampseros kurtzii Bacig.: -; -; L78063; -; -; -; -; -. Anacampseros marlothii Poelln.: -; -; -; -; HQ620849; -; -; -. Anacampseros papyracea E. Mey. ex Sond.: -; -; -; -; -; -; AM235079; -. Anacampseros pisina G.Will.: -; -; -; -; HQ620850; -; -; -. Anacampseros quinaria E.Mey. ex Sond.: -; -; L78012; -; -; -; -; -. Anacampseros recurvata Schönland: -; -; L78014; -; -; -; -; -. Anacampseros retusa Poelln.: -; -; -; -; DQ855860; DQ855873, AF194833; -; -. Anacampseros sp.: -; -; L78015, L78016, L78017, L78059; -; -; -; -; -. Anacampseros subnuda Poelln.: -; -; -; -; DQ855861; DQ855874; -; -. Anacampseros telephiastrum DC.: -; -; -; -; AY875373, DQ855862; DQ855875; AY875247; -. Grahamia australiana (J.M.Black) G.D.Rowley: -; -; -; -; DQ855855; -; -; -. Grahamia bracteata Gillies ex Hook. \& Arn.: -; -; L78028; -; AY015273; AF194846; AY875217; -. Grahamia coahuilensis (S.Watson) G.D.Rowley: -; -; -; -; DQ855854; -; AY875246; -. Grahamia frutescens (A.Gray) G.D.Rowley: -; -; -; -; DQ855851; DQ855871; -; -. Grahamia kurtzii (Bacig.) G.D.Rowley: -; -; -; -; DQ855853; -; -; -. Grahamia vulcanensis (Añon) G.D.Rowley: -; -; -; -; DQ855852; -; -; -. Talinopsis frutescens A. Gray: -; -; JF508607, L78058; -; -; AF194863; -; -. Talinaria palmeri Brandegee: -; -; L78052; -; -; -; -; -. Xenia vulcanensis (Añon) Gerbaulet: -; -; L78060; -; -; -; -; -. PORTULACACEAE: Avonia albissima (Marloth) G.D.Rowley; -; -; -; -; DQ855856; -; -; -. Avonia papyracea (E.Mey. ex Fenzl) G.D.Rowley; -; -; -; -; DQ855857; -; -; -. Avonia recurvata (Schönland) G.D.Rowley; -; -; -; -; DQ855858; -; -; -. Calandrinia axilliflora Barnéoud; -; -; DQ090290, DQ090291; -; JQ780477; -; -; -. Calandrinia ciliata (Ruiz \& Pav.) DC.: -; -; AY764087, DQ090292, L78021; -; AY764127; AF194835; -; -. Calandrinia colchaguensis Barnéoud; -; -; -; -; JQ780478; -; -; -. Calandrinia compressa Schrad. ex DC.: -; -; -; -; -; AF194836; -; -. Calandrinia volubilis Benth.: -; -; -; -; -; AF194838; -; -. Calyptrotheca somalensis Gilg; -; -; -; -; AY042563; AF194839; -; AF101139. Ceraria fruticulosa H.Pearson \& Stephens; -; -; -; -; AY875371; AF194841; AY875218; AF101141. Ceraria longipedunculata Merxm. \& Podlech; -; -; L78022; -; HQ620854; -; -; -. Ceraria namaquensis (Sond.) H.Pearson \& Stephens; -; -; L78023; -; HQ620855; -; -; -. Ceraria pygmaea (Pillans) G.D.Rowley; -; -; L78044; -; HQ620856; -; -; AF101140. Cistanthe grandiflora (Lindl.) Schltdl.: -; -; FJ614056, HM116396; -; -; AF194842; -; -. Cistanthe guadalupensis (Dudley) Carolin ex M.A.Hershkovitz; -; -; -; -; -; AF194860; -; -. Cistanthe laxiflora (Phil.) Peralta \& D.I.Ford; -; -; -; -; HQ620858; -; -; -. Cistanthe mucronulata (Meyen) Ford; -; -; -; -; HQ620860; AF194843; -; -. Cistanthe paniculata (Ruiz \& Pav.) Carolin ex M.A.Hershkovitz; -; -; -; -; HQ620861; -; -; -. Cistanthe picta (Gillies ex Arn.) Carolin ex M.A.Hershkovitz; -; -; DQ090232; -; HQ620862; -; -; -. Cistanthe tweedyi (A.Gray) Hershkovitz; -; -; -; -; JQ780479; -; -; -. Neopaxia erythrophylla Heenan; -; -; AY764082; -; AY764123; -; -; -. Neopaxia racemosa (Buchanan) Heenan; -; -; AY764084; -; AY764124; -; -; -. Portulaca amilis Speg.: -; -; -; -; HQ620886; -; -; - . Portulaca bicolor F.Muell.: -; -; -; -; DQ855848; -; -; -. Portulaca confertifolia Hauman: -; -; -; -; HQ620887; -; -; -. Portulaca eruca Hauman: -; -; -; -; DQ855849; -; -; -. Portulaca fluvialis D. Legrand: -; -; -; -; EU834750; -; -; -. Portulaca grandiflora Hook.: AF479093; AF207000; HM116403, JF508549; AF209659; EU834751; AF194853; M62568; -. Portulaca howellii (D. Legrand) Eliasson: -; -; -; -; HQ620888; -; -; Portulaca oleracea L.: -; HQ843437; JF508573, JF508575, JF508577; HQ620749; AY875349; AF194867; HQ621340; -. Portulaca pilosa L.: -; -; -; -; FN868304; -; HQ621340; -. Portulacaria afra Jacq.: -; -; L78042; HQ620747; AY875368; AF194857; 
Appendix 1. Continuation.

AY875219; AF101142. Portulacaria armiana van Jaarsv.: -; -; L78043; -; -; -; -; -. Portulacaria sp.: -; -; -; -; -; -; AB586510; -- CACTACEAE: Austrocylindropuntia subulata (Muehlenpf.) Backeb.: -; -; -; -; -; -; AY875235; -. Austrocylindropuntia vestita (SalmDyck) Backeb.: -; -; -; -; -; DQ855878; -; -. Blossfeldia liliputana Werderm.: -; -; AY064349; HQ620742; HM041655; -; AY875232; HM041389. Brasiliopuntia brasiliensis (Willd.) A.Berger: -; -; -; -; -; -; AY875234; -. Browningia hertlingiana (Backeb.) Buxb.: -; -; -; -; -; -; FR853281; -. Calymmanthium substerile F.Ritter: -; -; -; -; -; -; FR853389; -. Cereus fernambucensis Lem.: -; -; -; -; -; -; AY875240; -. Cylindropuntia spinosior (Engelm.) F.M.Knuth: -; -; -; -; -; -; JN796947; -. Echinocactus platyacanthus Link \& Otto: -; -; -; -; -; -; JN796938; -. Echinopsis aurea Britton \& Rose: -; -; -; -; -; -; FR853367; -. Ferocactus wislizeni (Engelm.) Britton \& Rose: -; -; -; -; -; -; JN796938; -. Hatiora cylindrica Britton \& Rose: -; -; -; -; -; -; FR853381; -. Hatiora herminiae (Porto \& A.Cast.) Backeb. ex Barthlott: -; -; -; -; -; -; FR853321; -. Hatiora salicornioides Britton \& Rose: -; -; -; -; -; -; FR853289; -. Lepismium lumbricoides (Lem.) Barthlott: -; -; -; -; -; -; FR853386; -. Maihuenia patagonica (Phil.) Britton \& Rose: -; -; L78031; -; -; DQ855877; AY875245; HM041447. Maihuenia poeppigii (Otto ex Pfeiff.) F.A.C.Weber: -; -; -; HQ620744; -; HQ620944; HQ621336; AY851609, AF191656. Maihueniopsis subterranea (R.E. Fr.) E.F. Anderson: -; -; -; -; EU834746; -; -; -. Mammillaria magnimamma Haw.: -; -; -; -; HM041716; -; -; -. Opuntia decumbens Salm-Dyck: -; -; -; HQ620746; -; HQ620946; -; -. Opuntia dillenii (Ker Gawl.) Haw.: -; -; -; -; -; -; HM850211; -. Opuntia echios Howell: -; -; JF786932; -; HM041736; -; -; HM041472. Opuntia engelmannii Salm-Dyck: -; -; -; -; -; -; JN796944; -. Opuntia fragilis (Nutt.) Haw.: -; -; -; -; -; -; GQ248659; -. Opuntia guatemalensis Britton \& Rose: -; -; -; -; -; -; JQ590995; -. Opuntia humifusa (Raf.) Raf.: -; -; -; -; -; -; GQ248660; -. Opuntia maxima Salm-Dyck ex DC.: -; -; -; -; -; -; HM850212; -. Opuntia microdasys (Lehm.) Pfeiff.: HQ843456 -; HQ843432; HQ872501, HQ872583, JF786966; HQ843258; -; HQ843277; -; HM041480. Pachycereus pecten-aboriginum (Engelm. ex S.Watson) Britton \& Rose: -; -; -; -; HM041750; -; -; -. Pereskia aculeata Mill.: AF479092; AF206986; HQ872561, JF508526; AF209648; -; DQ855876; M97888; HM041494, AY851589. Pereskia grandifolia Haw.: -; HQ901363; -; -; -; -; -; AY851603, AY851604. Pereskia lychnidiflora DC.: -; -; -; -; AY875358; -; AY875238; -. Pereskia portulacifolia (L.) DC.: -; -; -; -; AY875361; -; -; -. Pereskiopsis aquosa (F.A.C.Weber) Britton \& Rose: -; -; -; -; -; -; AY875225; -. Pereskiopsis diguetii (F.A.C.Weber) Britton \& Rose: -; -; -; HQ620748; -; -; HQ621339; -. Pereskiopsis porteri (Brandegee ex F.A.C.Weber) Britton \& Rose: -; -; -; -; -; -; AY875243; -. Quiabentia verticillata (Vaupel) Borg: -; -; -; -; HM041765; AF194858; AY875239; -. Quiabentia zehntneri (Britton \& Rose) Britton \& Rose: -; -; -; -; -; -; AY875236; -Rhipsalis baccifera (J.S.Muell.) Stearn: -; -; -; -; -; -; FR853282; -. Schlumbergera truncata (Haw.) Moran: -; -; -; -; -; -; M83543; -. Tephrocactus articulatus (Pfeiff.) Backeb.: -; -; -; -; -; -; AY875248; -. Weingartia kargliana Rausch: -; -; -; HQ620750; -; -; HQ621341; -. 